\author{
Military Technical College \\ Kobry El-Kobbah, \\ Cairo, Egypt
}

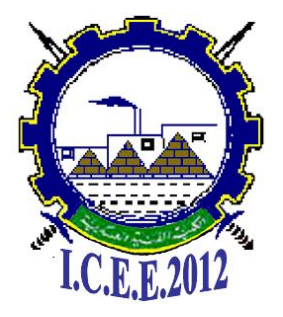

$6^{\text {th }}$ International Conference

on

Chemical \& Environmental

Engineering

29 -31 May, 2012.

\title{
ENMB-1
}

\section{FEASIBILITY OF EXTENDING THE COMPOSITE PROPELLANT POT LIFE}

\author{
Eng. Nagmeldin M. Amin", Dr. Eng. Bahaa Eldien M. Sidig*, Dr. Eng. M. H. Abuuznien ${ }^{* *}$,
}

\begin{abstract}
In composite propellant processing, propellant mixing and casting are the most complex and important operations. A solid propellant mixer must be capable of blending a mixture of solid/liquid ingredients with weight ratios as high as $90 \%$ solids and $10 \%$ liquids and resultant bulk viscosities ranging up to several kilopoise. Propellant mixing and casting processes are affected significantly by the rheological properties of the uncured propellant. ${ }^{1}$ Sometimes too short potlife is a great problem in propellant manufacturing particulary when the solid content is up to $87 \%$. The often used iron compounds generally even in small amounts also catalyze the curing reaction and shorten the pot life. ${ }^{2}$ many papers discused the developed methods for improving the composite propellant process by extending its pot life using some affected chemical materials. This work concentrated on a method for improving the manufacturing of the composite propellants dynamically, i.e without adding chemical materials to the propellant formula. This was done by delaying the addition of the curing agent to some hours. During this period a second standared mixing was carrying out. The comparison between the tow kinds of mixing was done to study the effect of the delaying of addition of the curing agent. It was found that viscosity build up test give similar reading for both kinds, which means that the propellant viscocity was not affected by this delaying. It was also found that, the mechanical and performance properties not affected by this step. It confirmed that delaying of the addition of the curing agent in the mixing process can be applied successfully.
\end{abstract}

Keywords: Composite Propellant, Propellant Curing, Potlife.

\footnotetext{
* Department of Chemical Engineering Karary University - Sudan

** Associate Professor, Head of Department of Chemical Engineering, Karary University Sudan
} 


\section{Nomenclature}

\begin{tabular}{|l|l|}
\hline AP & Ammonium per-chlorate \\
\hline HTPB & Hydroxyl Terminated Poly-butadiene \\
\hline m-TMXDI & m-Tetramethylxylene Diisocyanate \\
\hline TDI & Toluene Diisocyanate \\
\hline $\mathrm{C}^{*}(\mathrm{~m} / \mathrm{s})$ & Charcteristic Velocity \\
\hline $\mathrm{C}_{\mathrm{F}}$ & Thrust Coefficient \\
\hline $\mathrm{F}(\mathrm{N})$ & Thrust \\
\hline $\mathrm{I}_{\mathrm{sp}}(\mathrm{m} / \mathrm{s})$ & Specific Impulse \\
\hline $\mathrm{P}_{\mathrm{b}}(\mathrm{MPa})$ & Prssure \\
\hline $\mathrm{r}_{\mathrm{b}}(\mathrm{m} / \mathrm{s})$ & Rate of Burning \\
\hline $\mathrm{t}_{\mathrm{b}}(\mathrm{s})$ & Burning Time \\
\hline
\end{tabular}

\section{Introduction}

Composite propellants often contain transition metal compounds as burning rates modifiers. These additives accelerate the curing reaction after the addition of curing agent during mixing process. Different methods have been proposed to extend the pot life. ${ }^{2}$ Based on the process, the addition of some chemical materials affect the pot life of the propellant slurry, some of them decrease and others increase the pot life. Any of these materials used according to the process requirements. The "pot life" of the propellant slurry can be defined by many different terms. It is defined as the period of time during which a thermosetting plastic composition remains suitable for its intended use after mixing with a reaction-initiating agent. It is also called the working life or the usable life. ${ }^{3}$ Sometimes, It is defined as the time available for accomplishing the processing steps of mixing and casting propellant before the propellant loses its fluid nature. ${ }^{4}$

An empirical model that describes the change in viscosity of various formulations of propellant slurry with time and temperature has been developed. The model incorporates constants that account for the viscosity of the slurry caused by the combined effect of the continuous binder phase, dispersed particulate solids, and progress of cross-linking between reactive species of the binder and curators. The experimental method and approach used for data analysis can be used for other slurries that are similar in composition to propellant slurry. ${ }^{5}$ Different composite propellant mixtures have been prepared using ammonium perchlorate (AP), aluminum powder (Al) and hydroxyl terminated poly-butadiene (HTPB) by varying the percentage of plasticizer and addition of toluene diisocyanate (TDI) at different temperatures, and studied their different properties such as viscosity build-up, mechanical and ballistic properties and sensitivity. The data on different plasticizer level indicate that on decreasing the plasticizer content, there is a significant enhancement in end of mix viscosity, tensile strength and modulus while elongation decreases drastically. The data on sensitivity of the studied mixtures reveal that on decreasing the percentage of plasticizer, the sensitivity increases, accordingly. Further, the data on the effect of addition of TDI at different temperatures $\left(35-60{ }^{\circ} \mathrm{C}\right)$ there is a decrease in end of mix viscosity i.e. $800 \mathrm{~Pa} \mathrm{~s}$ at $35^{\circ} \mathrm{C}$ to $448 \mathrm{~Pa} \mathrm{~s}$ at $60^{\circ} \mathrm{C}$. Moreover, there is no effect on mechanical and ballistic properties on higher temperature, addition of TDI was observed. ${ }^{6}$ 


\section{Methods For Icreasing Pot-Life}

A research paper ${ }^{7}$ analyzed the viscosity and mechanical characteristics based on HTPB and three different types of curing agents including isocyanate's groups: DDI, IPDI and TDI. Along with the burning rate and pressure exponent levels, considering also the appropriaty of these formulations for application, show that the largest change of viscosity throughout measuring occurred in DDI propellants and for IPDI and TDI propellants three times respectively. Up to 81 mass\% solid content viscosity values for all of the three propellant types are very close. However, for heavy formulations (86 mas. \% solids and more), DDI propellants have the highest viscosity and therefore it can be concluded that this curing agent is not suitable for application in case of extremely heavy formulations. Larger $\mathrm{Al}$ amount for the same solid content is a more advantageous combination for the viscosity level ${ }^{7}$

An other paper described the use of a well known antibiotic (oxytetracycline) to increase the propellant pot life by virtue of its complex forming property and its structure providing good possibility for metal complex formation and the antibiotic activity is considered to depend on its metal binding function. By adding oxytetracyclene, this problem is easily eliminated and about the same potlives are obtained as for propellants with no iron compounds. Potlives have been successfully extended upto 2 to 3 hours. Mechanical propeties of oxytetracycline containing propellants are better than propellants without oxytetracyline. ${ }^{2}$

A new series of composite propellant compositions, have been developed with toluene diisocyanate (TDI), isophorone diisocyanate (IPDI) and a mixture of both curatives, to study their effect on processability, mechanical and ballistic properties of the compositions. The data indicate that the compositions based on bicurative have a pot life of 7-8 h, viscosity build up is from 13280 to 14080 poise after 4 hours, and the smooth processability of the slurry is enhanced. Further, the mechanical properties are in the range of $12.2 \mathrm{~kg} / \mathrm{cm}^{2}, 40.2 \mathrm{~kg} / \mathrm{cm}^{2}$ and $40.2 \%$ for tensile strength, E-modulus and elongation, respectively, and burning rate is almost the same. ${ }^{8}$ The pot life of TDI cured propellant is only in the order of $4-5$ houres. IPDI is preferred to TDI mainly on its slow reactivity, resulting in much extended pot life i.e. 15-18 houres as well as low toxicity. ${ }^{9,10}$ The reaction products formed from tri-functional aziridinylphosphine oxides and their derivatives reacted with monofunctional carboxylic acids, the tri-aziridinyl derivatives of triazine, the tri-aziridinyl derivatives of benzenetriacyl, the aziridine compound N-phenethylaziridine, and selected alkyl diaziridine compounds are representive of the aziridine compounds which are utilized in isocyanate curable composite propellant compositions to extend usable pot life required for mixing and processing of the specified compositions. ${ }^{11}$

Many other inventions were carried out described different methods for increasing the pot life of composite propellants such as treating and removing of ironic metals impurities. ${ }^{12}$ Addition of dicarboxylic acids such as maleic and oic acids. ${ }^{13}$ Addition of m-tetramethylxylene diisocyanate (m-TMXDI). ${ }^{14}$ Using polyols and polyamines. ${ }^{15}$ Incorporating into the propellant composition mix of organo-aluminum compound, tri (N-nitrosophenyl hydroxyl aluminum). ${ }^{16}$ using of glycerin. ${ }^{17}$

\section{Experimental Work}

The procedure used in this work was the delaying of the addition of the curing agent (TDI) for period ranged between 3 to 4 hours and then to continue the process to the end. In 
between, a standard mixing - without delaying of the addition of TDI was carried out. This mixing have a known range for the values of the readings of the viscosity build up, mechanical and performance properties. The standerd ranges for the mechanical properties were as shown in table (1) and The ranges for the performance properties are shown in table (2). The readings for the viscosity, the mechanical and the perfomance properties for many experiments were currid out and compaired with each other. Four experiments were achived. In experiment $\mathrm{No}(1)$ the amount of curing agent was $0.5 \%$ and the delaying time was $3 \mathrm{hrs}$. In experiment No (2) $0.45 \%$ of the curing agent was used with 3 hrs delaying time. $0.45 \%$ of curing agent was used in experiment No (3) with 4 hrs delaying time

\section{Results And Discussion}

Readings were carried out for the viscosity built up, mechanical and performance properties . The results were as follows:

i- Effect of delaying the addition of TDI on the viscosity build up readings is shown in tables (3 to 5)

From these tables, it was noticed that, in the experiment number 1 the diviation on the readings of the viscosity was big. This was due to the amount of the curing agent added, it was $0.5 \%$ by weight from the slurry amount. In the other experiments, the amount of the curing agent was decreased to $0.45 \%$ by weight. The diviation became small and the readings of the viscosity built up were nearly closed to eatch other. Even when the delay continued to 4 hours, the reading were still closed to each other.

ii- Effects of delaying the addition of TDI on the mechanical and performance properties are shown in tables (6 to 8)

From these tables, it is seen that in execpt of experiment number 1- the diviation on the readings of the mechanical and performance properties was small and the readings were nearly closed to eatch other, even when the delay is extended to 4 hours. The big diviations on experiment number 1 was also refered to the big amount of the curing agent added, which gave bad readings for some properties.

\section{Conclusion}

The experiments done and described in this work shows that, the dealy of the addition of the curing agent in the mixing process for sometime (up to 4 hours) doesn't affect nither the viscosity build up readings nor the mechanical and performance properties of the propellant. We can say that, in the manufacturing of HTPB/AP composite propellants, the delay of adding the curing agent to the propellant slurry can be applied successfully. This result can help the producer in filling one rocket motor by two mixing processes using a small mixer.

\section{References}

[1] Carlton L Horine; " Solid Propellant Processing Factors in Rocket Motor Design" NASA SP-8075, October 1971.

[2] Dr. Syed Zulfigar Hussain (Development of Energetic HTPB - Based Composite Propellant and Use of Oxytetracycline Antibiotic) from KRL/Pakistan.

[3] "Pot life definition" Sci-Tech Dictionary; www.wikianswers.com

[4] Cucksee, Marjorie T. and Allen, Henry C. "Extension of Pot Life of HTPB Composite Propellants by Phosphine Oxides" United States Patent 3, 974, 004, 1976. 
[5] R. Lakshmi, S. K. Athithan "An Empirical Model for the Viscosity Buildup of Hydroxy Terminated Polybutadiene Based Solid Propellant Slurry" Solid Propellant Space Booster Plant SHAR Centre, ISRO Sriharikota - 526 124, A. P. India.

[6] S.N. Jawalkar, Mehilal, K. Ramesh, K.K. Radhakrishnan and B. Bhattacharya "Studies on the Effect of Plasticiser and Addition of Toluene Diisocyanate at Different Temperatures in Composite Propellant Formulations" High Energy Materials Research Laboratory, Sutarwadi, Pune 411 021, India, August 2008.

[7] Rodić Vesna and Mirjana Petrić, (The effect of curing agents on solid composite rocket propellant Characteristics) Scientific-Technical Review, Vol.LV, No.1, 2005, UDK: 621.45.07-6:662.769, COSATI: 21-09.

[8] N.Jawalker, Mehilal, R. Kurva, P.P. Singh and B. Bhattacharya "Influence of Bicurative on Processibility of Composite Propelltant" Defence Science Jurnal, Vol. 57, No. 5, September 2007, Pp 669-675.

[9] Willacker, J.F; Edwards, G.R. \& Phillips, C.E. "IUS Solid Rocket Motor Useful Life Extension Programme" JANAF Propulsion Meeting, Vol. 480(1), CPTA, Dec. 1987, pp. 341-50.

[10] Butts, P.G; Hammod, R.N. \& Shdo, J. "IUS Propellant Development and Qualification” JANAF Propulsion Meeting, Vol. 370(1), CPTA, Feb. 1987.

[11] Marjorie T. Cuksee \& Henry C. Allen "Pot Life Extension of Isocyanate Cured Propellants by Aziridine Compounds" United State Patent Number: 4019933, Apr. 1977.

[12] Rudy, Thomas P. \& Nakagawa, Toshio W. "Purification of combustion catalysts and solid propellant compositions containing the same" United States Patent Number: 4, 166, 045, 1979.

[13] Ducote, Marjorie E. "Prevention of unwanted cure catalysis in isocyanate cured binders" United States Patent Number 4597811; July 1985.

[14] Ducote, Marjorie E. "TMXDI, Curing Agent for Hydroxy Terminated Propellant Binders" United States Patent 4913753, September 1989.

[15] Babjak, John R. and Yokoyama, Thomas W. "Method for Extending the Pot-life of Polyol-polyisocyanate Mixtures" United States Patent 5157100.

[16] Sayles, David C. "Method of Controlling the Increase in Pot Life of Propellants During Processing" United States Patent 5112417, 05/12/1992

[17] Makoto Kohga "From Cross-linking to Plasticization - Characterization of Glycerin/HTPB Blends" Propellants, Explosives, Pyrotechnics. Volume 34, Issue 5, pages 436-443, October 2009. 
Table (1) Standerd ranges for the mechanical properties

\begin{tabular}{|c|c|c|c|c|}
\hline Property & Tensile strength & Extensibility & Density & Hardness \\
\hline Unit & $\mathrm{Mpa}$ & $\%$ & $\mathrm{gm} / \mathrm{cm}^{3}$ & $\mathrm{Mpa}$ \\
\hline Range & $0.75-1.2$ & $35-45$ & $1.75-1.77$ & $45-65$ \\
\hline
\end{tabular}

Table (2) Standard ranges for the performance properties

\begin{tabular}{|c|c|c|c|c|c|c|c|}
\hline property & $\begin{array}{c}\text { Burning } \\
\text { time }\end{array}$ & $\begin{array}{c}\text { Burning } \\
\text { rate }\end{array}$ & $\begin{array}{c}\text { Avarage } \\
\text { pressure }\end{array}$ & $\begin{array}{c}\text { Avarage } \\
\text { thrust }\end{array}$ & $\begin{array}{c}\text { Characteristic } \\
\text { velosicty }\end{array}$ & $\begin{array}{c}\text { Specific } \\
\text { impulse }\end{array}$ & $\begin{array}{c}\text { Thrust } \\
\text { coefficient }\end{array}$ \\
\hline unit & $\mathrm{S}$ & $\mathrm{m} / \mathrm{s}$ & $\mathrm{MPa}$ & $\mathrm{kN}$ & $\mathrm{m} / \mathrm{s}$ & $\mathrm{N} . \mathrm{s} / \mathrm{kg}$ & - \\
\hline range & $0.8-1.2$ & $16-19$ & $4-6$ & $3-5$ & $1300-1600$ & $\begin{array}{c}2000- \\
2400\end{array}$ & $1.4-1.6$ \\
\hline
\end{tabular}

Table (3) Viscosity built up for experiment No.1

\begin{tabular}{|c|c|c|}
\hline \multirow{2}{*}{ Statement } & \multicolumn{2}{|c|}{ Viscosity Readings poise } \\
\cline { 2 - 3 } & $\begin{array}{c}\text { Standard } \\
\text { mixing }\end{array}$ & $\begin{array}{c}\text { Delay addition } \\
\text { of TDI to } 3 \mathbf{h}\end{array}$ \\
\hline 1 & 43.92 & 50.00 \\
\hline 2 & 39.34 & 44.03 \\
\hline 3 & 46.20 & 55.33 \\
\hline 4 & 58.13 & 73.13 \\
\hline 5 & 78.47 & 96.07 \\
\hline 6 & 105.74 & 119.98 \\
\hline 7 & 141.99 & 152.89 \\
\hline
\end{tabular}

Table (4) Viscosity built up for experiment No.2

\begin{tabular}{|c|c|c|}
\hline \multirow{2}{*}{ Statement } & \multicolumn{2}{|c|}{ Viscosity Readings poise } \\
\cline { 2 - 3 } & $\begin{array}{c}\text { Standard } \\
\text { mixing }\end{array}$ & $\begin{array}{c}\text { Delay addition } \\
\text { of TDI to } 3 \mathbf{h}\end{array}$ \\
\hline 1 & 28.24 & 21.53 \\
\hline 2 & 30.16 & 24.03 \\
\hline 3 & 40.14 & 36.05 \\
\hline 4 & 47.53 & 52.27 \\
\hline 5 & 63.29 & 58.77 \\
\hline 6 & 80.61 & 76.30 \\
\hline 7 & 99.82 & 97.56 \\
\hline
\end{tabular}

Table (5) Viscosity built up for experiment No.3

\begin{tabular}{|c|c|c|}
\hline \multirow{2}{*}{ Statement } & \multicolumn{2}{|c|}{ Viscosity Readings poise } \\
\cline { 2 - 3 } & $\begin{array}{c}\text { Standard } \\
\text { mixing }\end{array}$ & $\begin{array}{c}\text { Delay addition } \\
\text { of TDI to 4h }\end{array}$ \\
\hline 1 & 43.92 & 36.43 \\
\hline 2 & 39.34 & 35.10 \\
\hline 3 & 46.20 & 44.18 \\
\hline 4 & 58.13 & 60.27 \\
\hline 5 & 78.47 & 71.32 \\
\hline 6 & 105.74 & 90.22 \\
\hline 7 & 141.99 & 131.46 \\
\hline
\end{tabular}


Table (6) Mechanical and performance properties for experiment No.1

\begin{tabular}{|l|c|c|}
\hline Property & $\begin{array}{c}\text { Standard } \\
\text { mixing }\end{array}$ & $\begin{array}{c}\text { Delay } \\
\text { addition of } \\
\text { TDI to 3h }\end{array}$ \\
\hline Tensile $(\mathrm{MPa})$ & 0.62 & 0.986 \\
\hline Extensibility $(\%)$ & 34.52 & 34.992 \\
\hline Hardness & 44 & 54 \\
\hline Density $\left(\mathrm{g} / \mathrm{cm}^{3}\right)$ & 1.76 & 1.76 \\
\hline $\mathrm{t}_{\mathrm{b}}(\mathrm{s})$ & 0.965 & 1.003 \\
\hline $\mathrm{P}_{\mathrm{b}}(\mathrm{MPa})$ & 5.143 & 5.085 \\
\hline $\mathrm{C}^{*}(\mathrm{~m} / \mathrm{s})$ & 1376.9 & 1393.3 \\
\hline $\mathrm{r}_{\mathrm{b}}(\mathrm{m} / \mathrm{s})$ & 16.87 & 16.32 \\
\hline $\mathrm{F}(\mathrm{N})$ & 3.197 & 3.274 \\
\hline $\mathrm{I}_{\mathrm{sp}}(\mathrm{m} / \mathrm{s})$ & 2033.4 & 2135.8 \\
\hline $\mathrm{C}_{\mathrm{F}}$ & 1.48 & 1.53 \\
\hline
\end{tabular}

Table (7) Mechanical and performance properties fo experiment No.2

\begin{tabular}{|l|c|c|}
\hline Property & $\begin{array}{c}\text { Standard } \\
\text { mixing }\end{array}$ & $\begin{array}{c}\text { Delay addition } \\
\text { of TDI to 3h }\end{array}$ \\
\hline Tensile $(\mathrm{MPa})$ & 0.87 & 0.96 \\
\hline Extensibility $(\%)$ & 35.26 & 36.03 \\
\hline Hardness & 58 & 65 \\
\hline Density $\left(\mathrm{g} / \mathrm{cm}^{3}\right)$ & 1.76 & 1.76 \\
\hline $\mathrm{t}_{\mathrm{b}}(\mathrm{s})$ & 0.802 & 0.767 \\
\hline $\mathrm{P}_{\mathrm{b}}(\mathrm{MPa})$ & 6.505 & 6.344 \\
\hline $\mathrm{C}^{*}(\mathrm{~m} / \mathrm{s})$ & 1598.1 & 1511.4 \\
\hline $\mathrm{r}_{\mathrm{b}}(\mathrm{m} / \mathrm{s})$ & 18.96 & 19.98 \\
\hline $\mathrm{F}(\mathrm{N})$ & 4.196 & 4.163 \\
\hline $\mathrm{I}_{\mathrm{sp}}(\mathrm{m} / \mathrm{s})$ & 2356.4 & 2346.3 \\
\hline $\mathrm{C}_{\mathrm{F}}$ & 1.47 & 1.55 \\
\hline
\end{tabular}

Table (8) Mechanical and performance properties fo experiment No.3

\begin{tabular}{|c|c|l|}
\hline $\begin{array}{c}\text { Delay } \\
\text { addition of } \\
\text { TDI to 4h }\end{array}$ & $\begin{array}{c}\text { Standard } \\
\text { mixing }\end{array}$ & Property \\
\hline 0.968 & 1.094 & Tensile (MP) \\
\hline 40.662 & 40.848 & Extensibility $(\%)$ \\
\hline 55 & 57 & Hardness \\
\hline 1.76 & 1.75 & Density $\left(\mathrm{g} / \mathrm{cm}^{3}\right)$ \\
\hline 1.032 & 1.029 & $\mathrm{t}_{\mathrm{b}}(\mathrm{s})$ \\
\hline 5.338 & 5.327 & $\mathrm{P}_{\mathrm{b}}(\mathrm{MPa})$ \\
\hline 1546.9 & 1524.7 & $\mathrm{C}^{*}(\mathrm{~m} / \mathrm{s})$ \\
\hline 15.6 & 15.66 & $\mathrm{r}_{\mathrm{b}}(\mathrm{m} / \mathrm{s})$ \\
\hline 3.341 & 3.459 & $\mathrm{~F}(\mathrm{~N})$ \\
\hline 2296.4 & 2275.8 & $\mathrm{I}_{\mathrm{sp}}(\mathrm{m} / \mathrm{s})$ \\
\hline 1.48 & 1.49 & $\mathrm{C}_{\mathrm{F}}$ \\
\hline
\end{tabular}

